\title{
Current Status and Future Directions of mHealth Interventions for Health System Strengthening in India: Systematic Review
}

Abhinav Bassi ${ }^{1}$, BPT, MPH; Oommen John ${ }^{1,2}$, MBBS, MD; Devarsetty Praveen ${ }^{2,3}$, MBBS, MD, PhD; Pallab K Maulik $^{1,2,4}$, MSc, MD, PhD; Rajmohan Panda ${ }^{1}$, MD, MPH; Vivekanand Jha ${ }^{1,5}$, MD, DM, FRCP, FAMS



Corresponding Author:

Vivekanand Jha, MD, DM, FRCP, FAMS

George Institute for Global Health, India

311-312, Third Floor, Elegance Tower

Plot Number 8, Jasola District Centre

New Delhi, 110025

India

Phone: 911141588091

Email: vjha@georgeinstitute.org.in

\section{Abstract}

Background: With the exponential increase in mobile phone users in India, a large number of public health initiatives are leveraging information technology and mobile devices for health care delivery. Given the considerable financial and human resources being invested in these initiatives, it is important to ascertain their role in strengthening health care systems.

Objective: We undertook this review to identify the published mobile health (mHealth) or telemedicine initiatives in India in terms of their current role in health systems strengthening. The review classifies these initiatives based on the disease areas, geographical distribution, and target users and assesses the quality of the available literature.

Methods: A search of the literature was done to identify mHealth or telemedicine articles published between January 1997 and June 2017 from India. The electronic bibliographic databases and registries searched included MEDLINE, EMBASE, Joanna Briggs Institute Database, and Clinical Trial Registry of India. The World Health Organization health system building block framework was used to categorize the published initiatives as per their role in the health system. Quality assessment of the selected articles was done using the Cochrane risk of bias assessment and National Institutes of Health, US tools.

Results: The combined search strategies yielded 2150 citations out of which 318 articles were included (primary research articles=125; reviews and system architectural, case studies, and opinion articles=193). A sharp increase was seen after 2012, driven primarily by noncommunicable disease-focused articles. Majority of the primary studies had their sites in the south Indian states, with no published articles from Jammu and Kashmir and north-eastern parts of India. Service delivery was the primary focus of $57.6 \%(72 / 125)$ of the selected articles. A majority of these articles had their focus on $1(36.0 \%, 45 / 125)$ or $2(45.6 \%$, 57/125) domains of health system, most frequently service delivery and health workforce. Initiatives commonly used client education as a tool for improving the health system. More than $91.2 \%$ (114/125) of the studies, which lacked a sample size justification, had used convenience sampling. Methodological rigor of the selected trials $(n=11)$ was assessed to be poor as majority of the studies had a high risk for bias in at least 2 categories.

Conclusions: In conclusion, mHealth initiatives are being increasingly tested to improve health care delivery in India. Our review highlights the poor quality of the current evidence base and an urgent need for focused research aimed at generating high-quality evidence on the efficacy, user acceptability, and cost-effectiveness of mHealth interventions aimed toward health systems strengthening. A pragmatic approach would be to include an implementation research component into the existing and proposed digital health initiatives to support the generation of evidence for health systems strengthening on strategically important outcomes. 
(JMIR Mhealth Uhealth 2018;6(10):e11440) doi: 10.2196/11440

\section{KEYWORDS}

mHealth; telemedicine; health care system; India

\section{Introduction}

\section{Background}

Progress in the management of communicable diseases and reproductive maternal and child health conditions, combined with demographic transition, have caused a shift in the burden of mortality and morbidity to noncommunicable diseases (NCDs) [1]. In India, the contribution of NCDs to deaths increased from $37.9 \%$ in 1990 to $61.8 \%$ in 2016 [2]. The pauci-symptomatic nature and the long-term management and medication availability requirements force a change in the approach to NCD care delivery from facility-based service to domiciliary care, in which the consumer is not in constant contact with the health care system. Integrated care delivery is required using a risk factor-based rather than a disease-specific approach, with the need for periodic reassessment and treatment modification. Rural areas are at particular disadvantage due to the inadequacy and maldistribution of workforce and services.

Technological innovations present the possibility of turning a mobile device into a key component of health care delivery. Reduction in cost of handsets and increase in network coverage has led to a rapid expansion of mobile phone ownership in India. The number of mobile connections in India has grown to over 1 billion with $42 \%$ of the subscribers living in rural areas [3]. Out of 650 million active mobile users in 2017, nearly 300 million had a smartphone [4].

Mobile health or mHealth, defined by the global observatory for eHealth as "medical and public health practice supported by mobile devices, such as mobile phones, patient monitoring devices, personal digital assistants, and other wireless devices" is increasingly being used to support NCD care delivery [5]. Potential advantages include reducing response time by using trained nonphysician health workers, providing decision support, minimizing variability in the quality of delivered care, and optimizing monitoring and patient engagement, eventually reducing the cost of care and improving outcomes [6].

A number of initiatives that use mobile devices for delivering health care are currently being developed and implemented in India [6-9]. Given the considerable financial and human resources being invested in planning, development, and implementation of these initiatives, it is critical to ascertain their role in strengthening health care systems.

\section{Objectives}

We undertook this review to identify the published mHealth or telemedicine (provision of health care services using telecommunication technology) initiatives in India in the context of the health system building blocks and their potential for health systems strengthening. The review also presents the disease area, type of telecommunication device used, geographical distribution of the study sites, and target users of the innovation for these published mHealth initiatives in India. Finally, we highlight actions required for ensuring an effective role of mHealth interventions in strengthening the Indian health system.

\section{Methods}

\section{Search Strategy}

A search of the literature was done to identify mHealth or telemedicine articles published from India between January 1997 and June 2017. The electronic bibliographic databases and registries searched included MEDLINE, EMBASE, Joanna Briggs Institute EBP Database, World Health Organization's (WHO) International Clinical Trials Registry Platform, ClinicalTrial.gov, IndMED, and Clinical Trial Registry of India. The key search terms used included device (smartphones, cell phone, mobile phone, tablet, personal digital assistant, laptop, personal computer); service (Interactive Voice Response, text message, global positioning system, videoconferencing); intervention (primary care, secondary care, tertiary care, disease prevention, disease control, disease management, risk factor control, telemedicine, and mHealth); diseases (NCDs, communicable diseases, maternal, and child health); and India. The list of subheadings (MeSH) and text-words used along with the detailed strategy used for searching the databases is provided as Multimedia Appendix 1. The information technology (IT) devices included computers, fixed-line phones, personal digital assistants, feature phones, smartphones, and wearables. Articles related to the health effects of IT devices were excluded from this review.

We included primary research articles (trials, quasiexperimental, pre- and postintervention, cohort studies, descriptive and analytical cross-sectional studies, exploratory studies, and protocols for trials or quasi-experimental studies); review articles (systematic and narrative reviews); system description studies (describing system architecture); case studies; and opinion papers. A database was developed using Microsoft Office Access interface, and information was abstracted in 2 stages.

\section{Stage 1}

Year of publication and disease focus were abstracted for all the selected articles. The disease focus was classified under (1) communicable, maternal, perinatal, and nutritional conditions and (2) NCDs, using the WHO global health estimates classification [10].

\section{Stage 2}

Research articles containing primary data were carried forward to the second stage. Data related to geographical location, devices used, intended target users, target health system domain, and type of mHealth app or tool used were extracted. Review articles, system description studies, case studies, and opinion papers that did not have specific information on the above-mentioned indicators were excluded at this stage. 
The WHO health system building block framework was used to arrange the abstracted information under the following heads: (1) service delivery, (2) health workforce, (3) health information systems, (4) access to essential medicines, (5) financing, and (6) leadership or governance [11]. A framework developed by Labrique et al was used to classify the identified mHealth app or tool as per their types and uses [12]. We grouped all consumer-centric interventions by adding medical consultations offered through mobile technologies to the client education and behavior change communication. Health workers' awareness and perception of mHealth were included under provider training and education.

The Cochrane risk of bias assessment tool was used to assess the risk of selection bias, reporting bias, performance bias, detection bias, and attrition bias in randomized controlled trials (RCTs). Agency for Healthcare Research and Quality standards score was used to arrive at a composite indicator of quality (good, fair, and poor) for RCTs. Study quality was considered (1) "good" if it met all criteria (low for each domain, as per Cochrane risk of bias tool); (2) "fair" if the risk of bias was high for 1 domain or unclear for 2 and unlikely to have biased the outcomes; and (3) "poor" if 2 or more criteria had high or unclear risk of bias likely to have affected the outcomes. The quality assessment for observational cohort, pre-post and cross-sectional studies was done using the National Institutes of Health, US Department of Health and Human Services quality assessment tool [13]. Two reviewers (AB and $\mathrm{OJ}$ ) independently assessed the quality of the selected evidence. Any discordance in the selection, categorization, or quality assessment was resolved by discussion. The quality of the systematic reviews was assessed using the AMSTAR 2 checklist. AMSTAR 2 is a measurement tool created to assess the methodological quality of systematic reviews.

\section{Results}

\section{Search Results}

The combined search strategies yielded 2187 citations. After removing duplicates, a total of 1303 articles were screened for their relevance. Following the title and abstracts screening, a total of 886 articles were filtered out for criteria related to country, language, and nonrelevance. A total of 417 articles were selected for full-text evaluation. Exclusion of 99 articles not having mHealth or IT as the primary intervention resulted in the final selection of 318 articles (Figure 1).

Figure 2 shows the distribution of the articles and disease focus. Approximately $44.6 \%(142 / 318)$ of the selected articles had an NCD focus; $14.8 \%$ (47/318) were directed toward the domain of communicable, maternal, perinatal, and nutritional conditions; and the remaining $40.6 \%$ (129/318) addressed cross-cutting topics. The first 10 years (1997-2006) saw only a small number of articles with a focus on the role of telemedicine in improving the health services through medical consultations and communication between the health care providers. A sharp increase was seen after 2012, driven primarily by NCD-focused articles.
Table 1 presents distribution of the type of studies published between 1997 and 2017, divided into 5-year periods. Out of the 318 articles, more than $25.8 \%(82 / 318)$ were opinion-based articles, followed by $21.7 \%$ (69/318) descriptive and analytical cross-sectional studies. Less than $3.5 \%$ (11/318) followed an experimental design that allowed evaluation of the impact of interventions on the health outcomes. Most studies published between 1997 and 2006 were case studies or opinion articles.

A majority of studies had been conducted in the south Indian states, with Tamil Nadu (27) and Karnataka (24) leading the list. Delhi (17) and Maharashtra (13) had the highest number of sites from the rest of the country. No articles were published from Jammu and Kashmir and north-east Indian states. Moreover, 7 published articles reported findings from multicentric studies. A map of India with the distribution of the study sites is available (Figure 3) [14].

Figure 4 shows the devices used in the studies. Personal computers (desktops, notebooks) and fixed-line phones were the most commonly used tools until 2011. Articles using feature phones and smartphones as a technology device emerged after 2012.

A total of 125 articles provided information about the end users of the tool. Physicians were the most frequent end users $44.0 \%$ $(55 / 125)$, followed by patients $26.4 \%(33 / 125)$ and general community $10.4 \%(13 / 125)$. Only $6.4 \%$ (8/125) of the initiatives aimed at engaging community health workers.

\section{Risk of Bias and Quality Assessment}

Table 2 presents the risk of bias assessment for the selected RCTs. Overall, the methodological rigor of the included studies was poor. One study [15] had low risk of bias in all categories, whereas others had a high risk of bias in 2 or more categories. Moreover, 4 studies failed to provide enough information to allow assessment of risk of selection, performance, or detection bias (ie, unclear risk of bias).

Multimedia Appendices 2-4 provide details of quality assessment of the studies. More than $40 \%(44.8 \%, 56 / 125)$ of the cross-sectional studies had stated their research objectives or questions (Multimedia Appendix 2). Criterion related to description of the study population, demographics, clinical profile, and recruitment location was satisfied in $70 \%$ (48/69) of the studies. Sample size justification was not provided in more than $90 \%$ (62/69) of studies, with convenience sampling being the commonest approach. Only $15 \%$ (10/69) of the cross-sectional studies reported adjusting for potential confounders. Definition of the exposure (independent variables) and outcome measures (dependent variables) was present in approximately $60 \%(40 / 69)$ of the studies.

All the 4 cohort studies had stated their objectives and defined study populations (Multimedia Appendix 3). However, none of the studies had provided justification for the chosen sample size. All 4 studies used clearly defined, accepted methods for assessment of both exposure and control groups. Only 2 studies reported loss to follow-up. 
Figure 1. Preferred Reporting Items for Systematic Reviews and Meta-Analyses (PRISMA) flow diagram.

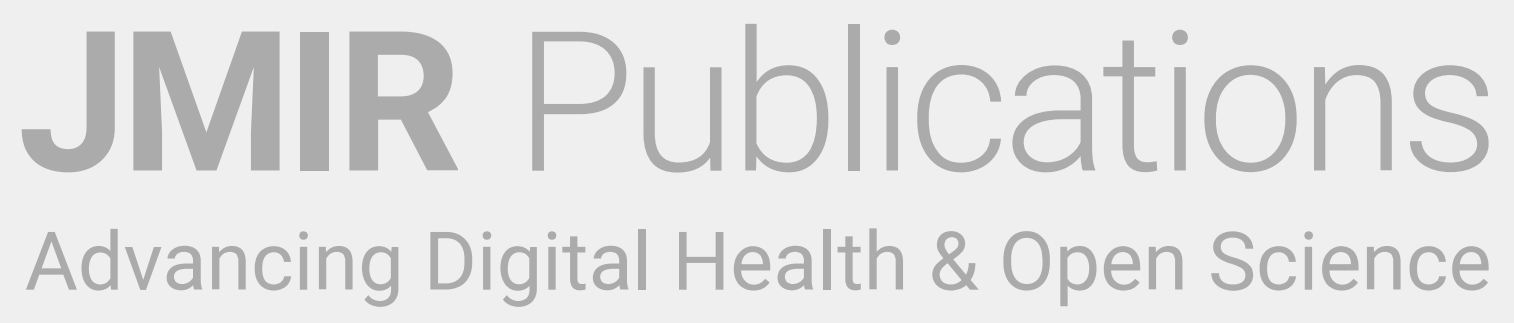


Figure 2. Year-wise distribution of the published articles and disease area.

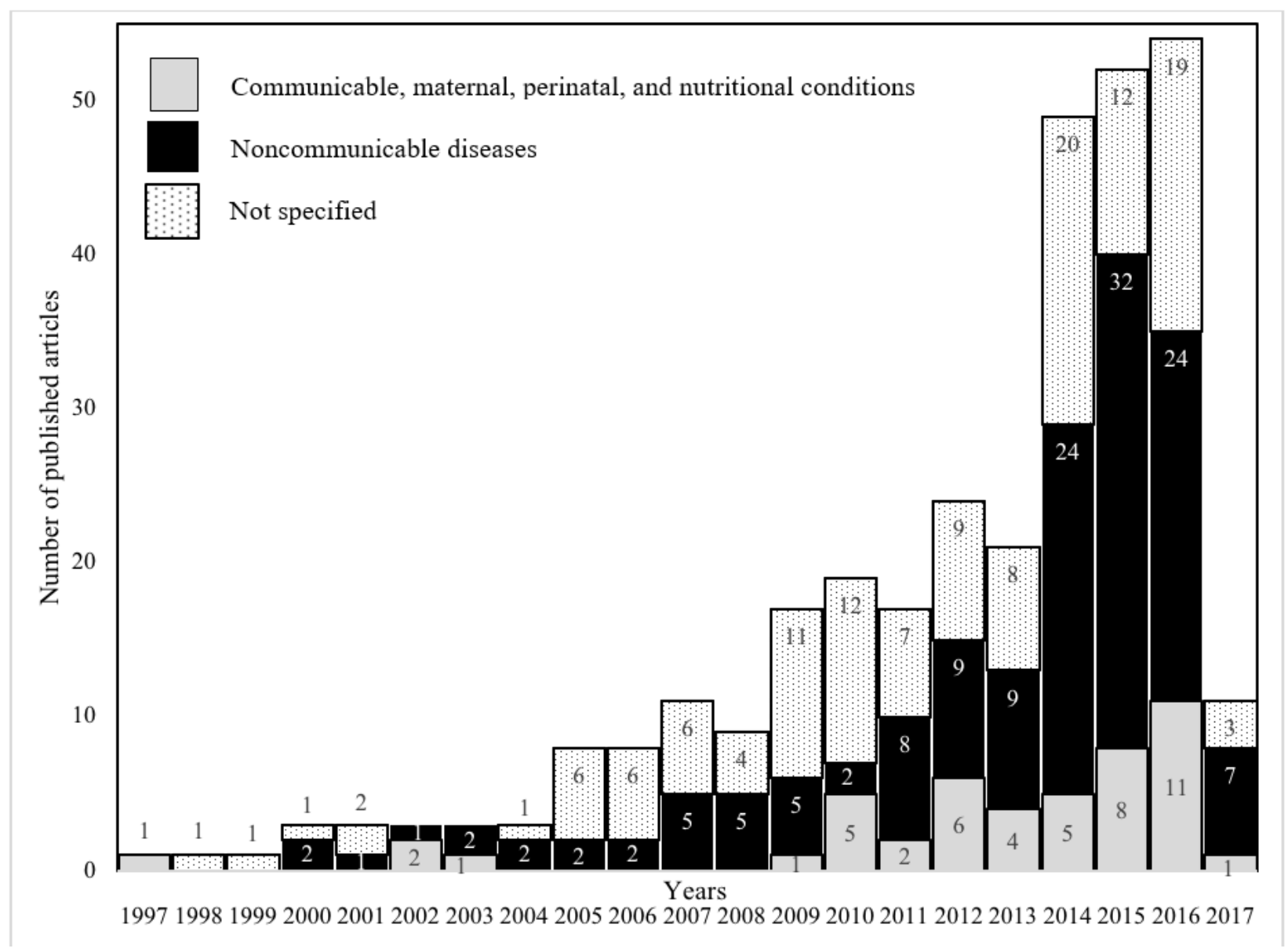

Table 1. Year-wise distribution of the type of published articles.

\begin{tabular}{lllllll}
\hline Serial number & Study type & \multicolumn{2}{c}{ Period in years } & & \multicolumn{2}{c}{ Articles, $\mathrm{n}(\%)$} \\
& & $1997-2001$ & $2002-2006$ & $2007-2011$ & $2012-2017$ \\
\hline 1 & Trials & $-{ }^{\mathrm{a}}$ & - & 2 & 9 & $11(3.4)$ \\
2 & Quasi-experimental and pre-post intervention & - & - & 1 & 8 & $9(2.8)$ \\
3 & Cohort study & - & - & - & 4 & $4(1.3)$ \\
4 & Descriptive and analytical cross-sectional studies & - & 4 & 12 & 53 & $69(21.7)$ \\
5 & Exploratory & - & - & 5 & 21 & $26(8.2)$ \\
6 & Protocols (trials and quasi-experimental) & - & - & 1 & 5 & $6(1.9)$ \\
7 & Systematic and narrative reviews & - & - & 3 & 13 & $16(5)$ \\
9 & System architectural & - & - & 7 & 39 & $46(14.5)$ \\
10 & Case study & 2 & 8 & 19 & 20 & $49(15.4)$ \\
\hline
\end{tabular}

\footnotetext{
${ }^{\mathrm{a}}$ Not applicable.
} 
Figure 3. Geographical distribution of the study sites (n=125). Map source: Ministry of External Affairs, Government of India.

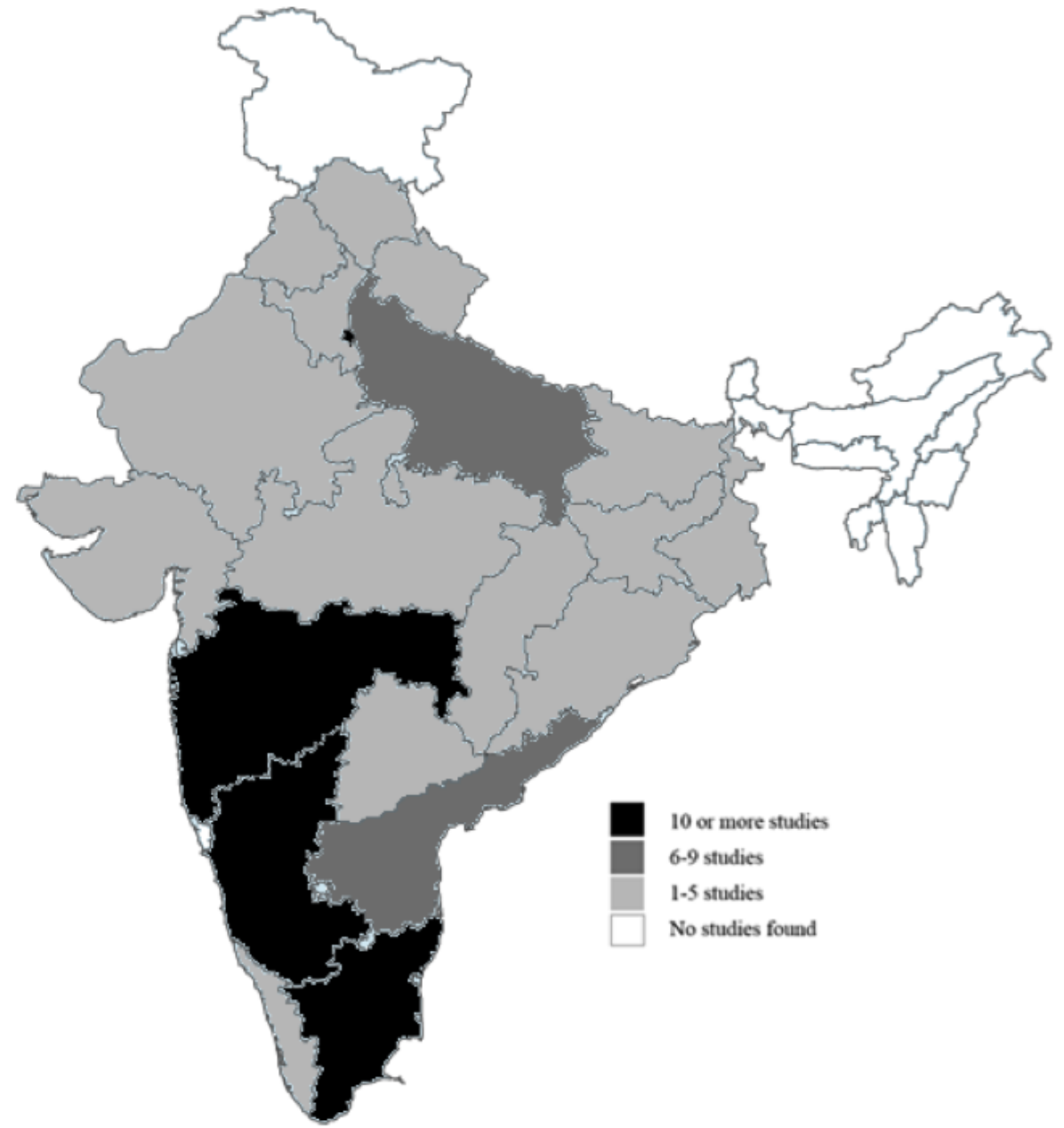

Figure 4. Changing preference of device used over time ( $\mathrm{n}=125)$.

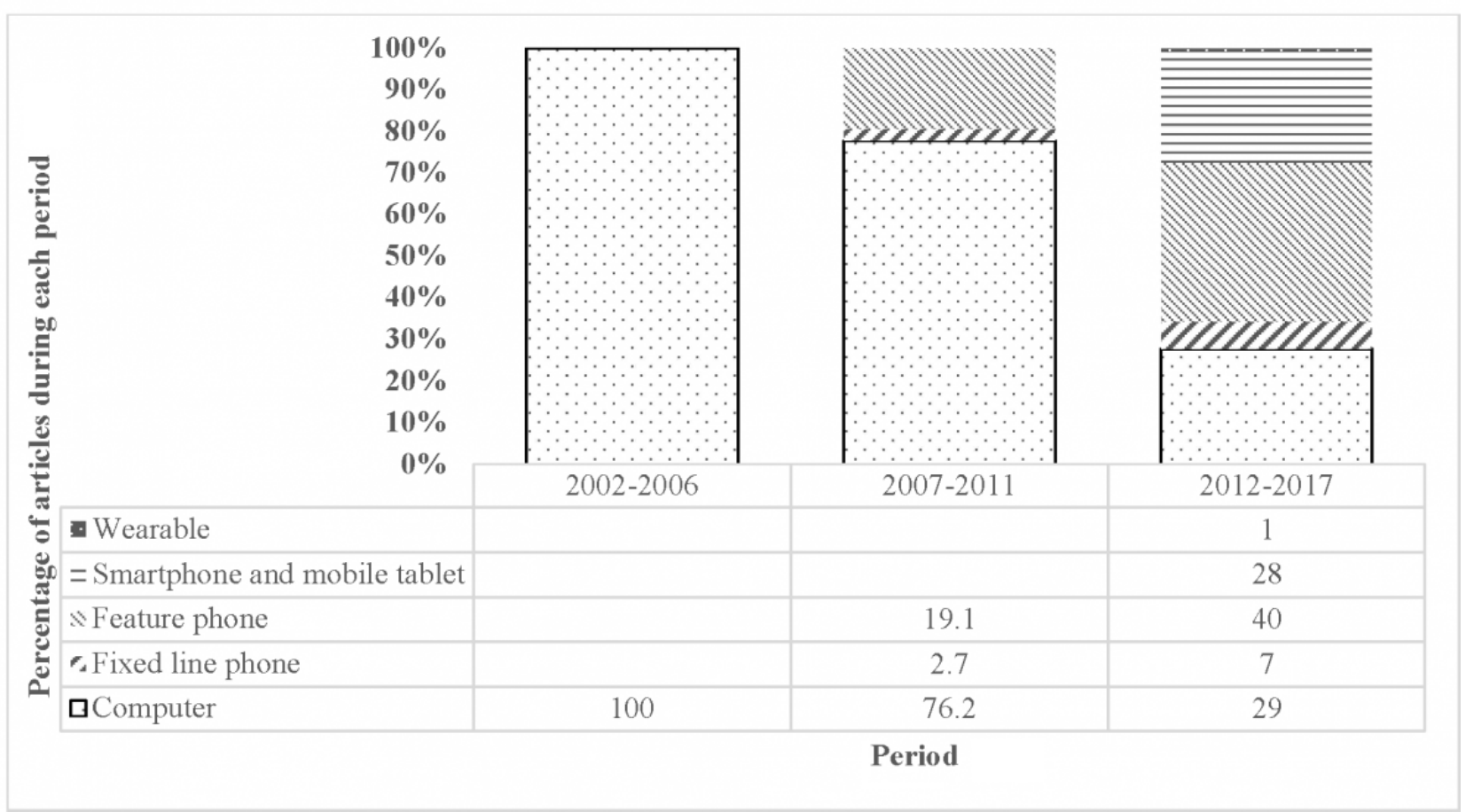


Table 2. Risk of bias assessment for randomized control trials.

\begin{tabular}{|c|c|c|c|c|c|c|c|c|}
\hline Author & $\begin{array}{l}\text { Random se- } \\
\text { quence genera- } \\
\text { tion }\end{array}$ & $\begin{array}{l}\text { Allocation } \\
\text { concealment }\end{array}$ & $\begin{array}{l}\text { Blinding (par- } \\
\text { ticipants and } \\
\text { personnel) }\end{array}$ & $\begin{array}{l}\text { Blinding (out- } \\
\text { come assessment) }\end{array}$ & $\begin{array}{l}\text { Selective } \\
\text { reporting }\end{array}$ & $\begin{array}{l}\text { Incomplete } \\
\text { outcome data }\end{array}$ & $\begin{array}{l}\text { Other sources } \\
\text { of bias }\end{array}$ & $\mathrm{AHRQ}^{\mathrm{a}}$ score \\
\hline $\begin{array}{l}\text { Arora et al, } \\
2017 \text { [15] }\end{array}$ & Low & Low & Low & Low & Low & Low & Low & Good \\
\hline $\begin{array}{l}\text { Jain et al, } 2010 \\
{[16]}\end{array}$ & Low & Low & High & Low & Low & Low & Low & Fair \\
\hline $\begin{array}{l}\text { Sharma et al, } \\
2011 \text { [17] }\end{array}$ & High & High & High & Unclear & Low & Low & $\mathrm{High}^{\mathrm{b}}$ & Poor \\
\hline $\begin{array}{l}\text { Prasad et al, } \\
2012[18]\end{array}$ & High & High & High & Unclear & Low & Low & Low & Poor \\
\hline $\begin{array}{l}\text { Ramachandran } \\
\text { et al, } 2013 \text { [19] }\end{array}$ & Low & Low & High & Low & Low & Low & Low & Fair \\
\hline $\begin{array}{l}\text { Radhakrishnan } \\
\text { et al, } 2014 \text { [20] }\end{array}$ & Low & Unclear & High & High & Unclear & Low & Low & Poor \\
\hline $\begin{array}{l}\text { Shet et al, } 2014 \\
\text { [21] }\end{array}$ & Unclear & Low & Low & Low & Low & Low & Low & Fair \\
\hline $\begin{array}{l}\text { Kaur et al, } 2015 \\
{[22]}\end{array}$ & Low & High & High & High & Low & Low & Low & Poor \\
\hline $\begin{array}{l}\text { Kumar et al, } \\
2015[23]\end{array}$ & Low & High & High & Low & Low & Low & Low & Poor \\
\hline $\begin{array}{l}\text { Patnaik et al, } \\
2015 \text { [24] }\end{array}$ & High & High & High & High & High & High & $\mathrm{High}^{\mathrm{c}}$ & Poor \\
\hline $\begin{array}{l}\text { Limaye et al, } \\
2017[25]\end{array}$ & Low & High & High & Low & Low & Low & Low & Poor \\
\hline
\end{tabular}

${ }^{\mathrm{a}}$ AHRQ: Agency for Healthcare Research and Quality.

${ }^{\mathrm{b}}$ Contamination and source of recruitment of the study subjects are not mentioned.

${ }^{\mathrm{c}}$ High and unequal attrition rates noted between the 2 study arms.

Table 3. Classification of the mHealth initiatives based on different health systems' building blocks and mHealth tools.

\begin{tabular}{|c|c|c|c|c|c|c|}
\hline \multirow[t]{2}{*}{ mHealth tools } & \multicolumn{6}{|c|}{ World Health Organization health system building block classification } \\
\hline & $\begin{array}{l}\text { Service } \\
\text { delivery }\end{array}$ & $\begin{array}{l}\text { Health work- } \\
\text { force }\end{array}$ & $\begin{array}{l}\text { Medical prod- } \\
\text { ucts, vaccines, } \\
\text { and technologies }\end{array}$ & $\begin{array}{l}\text { Health information } \\
\text { system }\end{array}$ & $\begin{array}{l}\text { Leadership and } \\
\text { governance }\end{array}$ & Total \\
\hline Client education and behavior change communication & 61 & $-{ }^{\mathrm{a}}$ & - & 1 & 1 & 63 \\
\hline Sensors and point-of-care diagnostics & 2 & - & 11 & - & - & 13 \\
\hline Provider training and education & - & 11 & - & - & 1 & 12 \\
\hline Provider-to-provider communication & 5 & 5 & - & - & - & 10 \\
\hline Electronic decision support & 3 & 5 & 1 & - & - & 9 \\
\hline Data collection and reporting & - & - & 1 & 3 & 1 & 5 \\
\hline Registries or vital event tracking & 1 & - & - & 4 & - & 5 \\
\hline Electronic health records & - & - & - & 3 & - & 3 \\
\hline Supply chain management & - & - & 1 & - & - & 1 \\
\hline
\end{tabular}

${ }^{\mathrm{a}}$ Not applicable.

Only 2 of the pre-post single group studies had a sufficient sample size, whereas others were feasibility studies with no sample size justification (Multimedia Appendix 4). Outcomes measures were defined in all, and 1 study had used a

nonvalidated tool for outcomes measurement. Outcome assessor blinding was not reported in any of the pre-post studies. Quality assessment of the 2 systematic reviews revealed methodological 
flaws including a lack of risk of bias assessment (Multimedia Appendix 5 [26,27]).

\section{Health Systems Building Blocks}

The classification in Table 3 is based on the primarily targeted health system building block and mHealth tool. Multimedia Appendix 6 provides details of the multiple health system building blocks targeted by each article. A majority of these articles had their focus on $1(36.0 \%, 45 / 125)$ or $2(45.6 \%$, $57 / 125)$ blocks, most frequently service delivery and health workforce. Approximately $16.8 \%$ (21/125) of the articles targeted 3 building blocks, and only $2.4 \%$ (3/125) of the articles had initiatives that had bearings on 4 building blocks of the health system.

\section{Health Service Delivery}

Nearly $57.6 \%(72 / 125)$ of the primary research articles had service delivery strengthening as a primary focus. Key activities covered included patient consultations, remote diagnosis, and follow-up through videoconferencing. Mobile phones were primarily used for treatment adherence reminders (text and Interactive Voice Response), appointment reminders, and behavior change messaging $(n=8)[18,21,28-33]$. Development process was described in 21 articles, 32 articles reported utility [16-25,30,31,34-57], and 20 articles reported user acceptability of the initiative $[28,32,33,58-74]$. Other aspects explored were technology-related perception of the end users $(n=13)$ [29,75-85], patient satisfaction $(n=2)[86,87]$, assessment of health care professional needs, and challenges related to health service delivery using IT $(\mathrm{n}=2)$ [88,89].

\section{Health Workforce}

Nearly $20.0 \%$ (25/125) of the articles had health workforce as the primarily targeted health system domain. Establishment of a provider-to-provider communication through teleconsultations, remote trainings, and capacity building was the most common health workforce strengthening activity. Objectives included reporting changes in the knowledge scores of the health care workers following tele-education interventions $(n=11)$ [90-100] or a survey of mHealth or telemedicine-related knowledge, attitude, and practice among the health care professionals without any intervention $(n=8)$ [16,101-108]. Articled describing use of mobile apps for screening, referral, guideline-based care, and provider work planning appeared only after 2013. Development and utility of community health worker-centric interventions that facilitated task shifting for disease screening, referral, and health information dissemination were discussed in 5 articles [109-113].

\section{Essential Medical Products, Vaccines, and Technologies}

Medical products and technology were the focus of $11.2 \%$ $(14 / 125)$ of the selected articles, with nearly half relating to eye care [114-121], specifically using remotely operated technological tools for disease diagnosis $(n=6)$ [115,118,122-125]. One study evaluated patient experience for health monitoring [126] and another evaluated a mobile-based vaccine management tool [127].

\section{Health Information}

In total, $8.8 \%(11 / 125)$ of the articles evaluated strengthening of the health information system, with focus on vital event tracking, disease surveillance, and case notification in rural areas [128-137]. Articles were mostly related to communicable diseases, maternal, perinatal, and nutritional conditions. One study evaluated mobile- and tablet-based systems for collection of data related to behavior research [138].

\section{Leadership, Governance, and Financing}

A total of 3 studies addressed leadership-, governance-, and financing-related issues. Finding the challenges related to the financing of the existing mHealth programs and the legal issues related to teleconsultations in India were the key objectives of these studies [139-141].

\section{Discussion}

\section{Principal Findings}

We describe, for the first time, the landscape of mHealth initiatives from a health system perspective from the second most populous country in the world that faces major challenges in health care delivery. The emerging evidence base around mHealth in India shows a progress from anecdotal telemedicine user stories to primary research articles, providing evidence on effectiveness in achieving the health objectives. The shift of focus of the mHealth initiatives over time toward NCDs is similar to the finding from China [142].

A notable finding was the concentration of mHealth solutions in a few states, with almost complete exclusion of the others, including some of the most underserved areas such as the north-eastern regions and Jammu and Kashmir, where mHealth might introduce great efficiency. A recent report by the Global Burden of Disease Study group pointed out at the heterogeneity of diseases and risk factors between Indian states [143]. Interstate variations in the structure and performance of health care delivery systems add to the challenge of last mile health care delivery. Therefore, it is important to test solutions in different states, especially the disadvantaged states that have the potential of experiencing the most transformative change.

The evolution in device choice may indicate changing consumer preferences in the contemporary mobile technology. However, the scientific basis for selecting these devices was not clearly articulated. Choice should take into account the technological know-how of end users, local health systems, nature of intervention, and availability of resources required to support the technology. The relevance of this knowledge becomes more important as these solutions are targeted to community health workers and patients to promote self-management and health promotion in communities.

Analysis in terms of the WHO health system building blocks revealed focus on service delivery and workforce strengthening, with relative neglect of health governance and health financing domains. Most of the reported mHealth interventions were being implemented as standalone solutions often with no health systems integration strategy. To reap maximal benefits, mHealth 
innovations should function as integrable tools that yield positive outcomes related to access, equity, quality, and responsiveness.

Client education, which increases access to health information, was the most widely used mHealth service delivery tool. However, contextual background to the health information that was being provided to the clients was not provided in the articles we reviewed. Similar findings in terms of the mHealth tools used emerged from China [142].

While assessing the studies for the methodological rigor, we found the use of nonvalidated instruments (survey and questionnaire) to be common. Sample size justification was provided only in a minority of reports. Use of convenience sampling has been a cause of prevalent skepticism related to mHealth interventions [144]. Another major flaw was the lack of a proper experimental design that allows generation of high-quality evidence. This combination of use of narrowly focused interventions in relatively small populations using loose experimental designs raises serious questions about internal as well as external validity of these studies, and this led to the use of a derisive term "pilotitis" to describe these mHealth studies.

\section{Limitations}

Any review is only as good as the quality of the studies that are included. Studies published in biomedical literature only represent a subset of mHealth interventions as a fair number of studies are never submitted to academic journals. The mHealth apps that are available through the app stores were outside the scope of this review. Moreover, conducting a meta-analysis to provide estimates of clinical or cost-effectiveness was not possible due to the large differences in the methodologies used and outcome variables. Finally, while reporting the focus of the interventions, we used WHO's health system building blocks and selected the primarily targeted health system domain. Caveat for interpreting these findings is that a number of interventions would have a synergistic effect on other health system domains. For instance, any intervention that is focused on capacity building of the health workforce would not only have an impact on the "health workforce" building block but would also improve the quality of care, thus strengthening the "service delivery."

\section{Conclusions}

In conclusion, mHealth initiatives are being increasingly tested to improve health care delivery in India. Despite the widespread perception that health care delivery capacity could be rapidly scaled up for achieving universal health coverage by leveraging the expanding mobile communications networks and high ownership of mobile devices, the quality of evidence remains suboptimal. Robust scientific evaluation of effectiveness through appropriately designed and sampled studies powered on clinical end points is critical for establishing the on-field appropriateness of mHealth initiatives. Our review highlights an urgent need for focused research aimed at generating high-quality evidence on efficacy and user acceptability of mHealth interventions aimed toward health systems strengthening considering contextual factors and size and specifics of the problems being addressed. We need well-designed, cost-effective studies to help policy makers use the finite health budgets to ensure maximum health benefits. A pragmatic approach would be to include an implementation research component into the existing and proposed digital health initiatives to support generation of evidence for health system strengthening on strategically important outcomes.

\section{Acknowledgments}

The authors would like to thank Qualcomm Wireless Reach for providing funding support.

\section{Conflicts of Interest}

None declared.

\section{Multimedia Appendix 1}

Search strategy for databases.

[PDF File (Adobe PDF File), 231KB-Multimedia Appendix 1]

\section{Multimedia Appendix 2}

Quality assessment for cross-sectional studies.

\section{[PDF File (Adobe PDF File), 75KB-Multimedia Appendix 2]}

\section{Multimedia Appendix 3}

Quality assessment for observational cohort.

[PDF File (Adobe PDF File), 30KB-Multimedia Appendix 3]

\section{Multimedia Appendix 4}

Quality assessment for pre-post studies. 
[PDF File (Adobe PDF File), 30KB-Multimedia Appendix 4]

\section{Multimedia Appendix 5}

Quality assessment of systematic reviews (AMSTAR 2).

[PDF File (Adobe PDF File), 29KB-Multimedia Appendix 5]

\section{Multimedia Appendix 6}

Study objectives, mHealth tool used, and health system framework classification of the selected articles.

[PDF File (Adobe PDF File), 135KB-Multimedia Appendix 6]

\section{References}

1. Yadav S, Arokiasamy P. Understanding epidemiological transition in India. Glob Health Action 2014;7:23248 [FREE Full text] [Medline: 24848651]

2. GBD 2016 Mortality Collaborators. Global, regional, and national under-5 mortality, adult mortality, age-specific mortality, and life expectancy, 1970-2016: a systematic analysis for the Global Burden of Disease Study 2016. Lancet 2017 Sep 16;390(10100):1084-1150 [FREE Full text] [doi: 10.1016/S0140-6736(17)31833-0] [Medline: 28919115]

3. Cellular Operators Association of India (COAI). Coai. 2017. Going Digital People, Places, Things Annual Report URL: https://coai.com/reports-and-papers/coai-annual-report [accessed 2018-06-29] [WebCite Cache ID 70WoaCixX]

4. Iyengar R. Money.cnn. 2017 Sep 28. India poised for smartphone revolution URL: http://money.cnn.com/2017/09/26/ technology/india-mobile-congress-market-numbers/index.html[WebCite Cache ID 70Wp20x2R]

5. World Health Organization. 2011. mHealth: New Horizons for Health through Mobile Technologies, Global Observatory for eHealth series URL: http://www.who.int/goe/publications/goe mhealth web.pdf [accessed 2018-10-05] [WebCite Cache ID 72xItOh4F]

6. Majumdar A, Kar SS, S GK, Palanivel C, Misra P. mHealth in the prevention and control of non-communicable diseases in India: current possibilities and the way forward. J Clin Diagn Res 2015 Feb;9(2):LE06-LE10 [FREE Full text] [doi: 10.7860/JCDR/2015/11555.5573] [Medline: 25859473]

7. Ananthakrishnan A, Shankar M, Chahar A, Kachroo K, Ameel M, Sharma J, et al. The use of mobile health technology in promoting infant vaccine adherence - a health technology assessment. Value Health 2015 Nov;18(7):A559 [FREE Full text] [doi: 10.1016/j.jval.2015.09.1813] [Medline: 26533141]

8. Sahu M, Grover A, Joshi A. Role of mobile phone technology in health education in Asian and African countries: a systematic review. Int J Electron Healthc 2014;7(4):269-286. [doi: 10.1504/IJEH.2014.064327] [Medline: 25161104]

9. Déglise C, Suggs LS, Odermatt P. SMS for disease control in developing countries: a systematic review of mobile health applications. J Telemed Telecare 2012 Jul;18(5):273-281. [doi: 10.1258/jtt.2012.110810] [Medline: 22826375]

10. World Health Organization. Health statistics and information systems Global Health Estimates (GHE) URL: http://www. who.int/healthinfo/global_burden_disease/en/[WebCite Cache ID 70WppdP8s]

11. World Health Organization. 2017. Health services development: the WHO health systems framework URL: http://www. wpro.who.int/health services/health systems framework/en/[WebCite Cache ID 70WpuVeGX]

12. Labrique AB, Vasudevan L, Kochi E, Fabricant R, Mehl G. mHealth innovations as health system strengthening tools: 12 common applications and a visual framework. Glob Health Sci Pract 2013 Aug;1(2):160-171 [FREE Full text] [doi: 10.9745/GHSP-D-13-00031] [Medline: 25276529]

13. National Heart, Lung, and Blood Institute (NHLBI). National Institute of Health . Study Quality Assessment Tools URL: https://www.nhlbi.nih.gov/health-topics/study-quality-assessment-tools[WebCite Cache ID 70WpuVeGX]

14. Ministry of External Affairs. 2017. Glance @ India URL: http://www.mea.gov.in/india-at-glance.htm [accessed 2018-06-29] [WebCite Cache ID 70WpzqsOn]

15. Arora M, Harvey LA, Glinsky JV, Chhabra HS, Hossain S, Arumugam N, et al. Telephone-based management of pressure ulcers in people with spinal cord injury in low- and middle-income countries: a randomised controlled trial. Spinal Cord 2017 Feb;55(2):141-147. [doi: 10.1038/sc.2016.163] [Medline: 27995939]

16. Jain A, Agarwal R, Chawla D, Paul V, Deorari A. Tele-education vs classroom training of neonatal resuscitation: a randomized trial. J Perinatol 2010 Dec;30(12):773-779. [doi: 10.1038/jp.2010.42] [Medline: 20357810]

17. Sharma R, Hebbal M, Ankola AV, Murugabupathy V. Mobile-phone text messaging (SMS) for providing oral health education to mothers of preschool children in Belgaum City. J Telemed Telecare 2011;17(8):432-436. [doi: 10.1258/jtt.2011.110416] [Medline: 22025742]

18. Prasad S, Anand R. Use of mobile telephone short message service as a reminder: the effect on patient attendance. Int Dent J 2012 Feb;62(1):21-26. [doi: 10.1111/j.1875-595X.2011.00081.x] [Medline: 22251033] 
19. Ramachandran A, Snehalatha C, Ram J, Selvam S, Simon M, Nanditha A, et al. Effectiveness of mobile phone messaging in prevention of type 2 diabetes by lifestyle modification in men in India: a prospective, parallel-group, randomised controlled trial. Lancet Diabetes Endocrinol 2013 Nov;1(3):191-198. [doi: 10.1016/S2213-8587(13)70067-6] [Medline: 24622367]

20. Radhakrishnan J, Swaminathan N, Pereira N, Henderson K, Brodie D. Effect of an IT-supported home-based exercise programme on metabolic syndrome in India. J Telemed Telecare 2014 May 14;20(5):250-258. [doi: 10.1177/1357633X14536354] [Medline: 24829259]

21. Shet A, De Costa A, Kumarasamy N, Rodrigues R, Rewari BB, Ashorn P, HIVIND Study Team. Effect of mobile telephone reminders on treatment outcome in HIV: evidence from a randomised controlled trial in India. Br Med J 2014;349:g5978 [FREE Full text] [Medline: 25742320]

22. Kaur R, Kajal KS, Kaur A, Singh P. Telephonic consultation and follow-up in diabetics: impact on metabolic profile, quality of life, and patient compliance. N Am J Med Sci 2015 May;7(5):199-207 [FREE Full text] [doi: 10.4103/1947-2714.157483] [Medline: 26110131]

23. Kumar S, Shewade HD, Vasudevan K, Durairaju K, Santhi VS, Sunderamurthy B, et al. Effect of mobile reminders on screening yield during opportunistic screening for type 2 diabetes mellitus in a primary health care setting: a randomized trial. Prev Med Rep 2015;2:640-644 [FREE Full text] [doi: 10.1016/j.pmedr.2015.08.008] [Medline: 26844130]

24. Patnaik L, Joshi A, Sahu T. Mobile phone-based education and counseling to reduce stress among patients with diabetes mellitus attending a tertiary care hospital of India. Int J Prev Med 2015;6:37 [FREE Full text] [doi:

10.4103/2008-7802.156267] [Medline: 25984287]

25. Limaye T, Kumaran K, Joglekar C, Bhat D, Kulkarni R, Nanivadekar A, et al. Efficacy of a virtual assistance-based lifestyle intervention in reducing risk factors for type 2 diabetes in young employees in the information technology industry in India: LIMIT, a randomized controlled trial. Diabet Med 2017 Dec;34(4):563-568. [doi: 10.1111/dme.13258] [Medline: 27589695]

26. Mushcab H, Kernohan WG, Wallace J, Martin S. Web-based remote monitoring systems for self-managing type 2 diabetes: a systematic review. Diabetes Technol Ther 2015 Jul;17(7):498-509. [doi: 10.1089/dia.2014.0296] [Medline: 25830528]

27. Devi BR, Syed-Abdul S, Kumar A, Iqbal U, Nguyen P, Li YJ, et al. mHealth: an updated systematic review with a focus on HIV/AIDS and tuberculosis long term management using mobile phones. Comput Methods Programs Biomed 2015 Nov;122(2):257-265. [doi: 10.1016/j.cmpb.2015.08.003] [Medline: 26304621]

28. Verma M, Raman R, Mohan RE. Application of tele-ophthalmology in remote diagnosis and management of adnexal and orbital diseases. Indian J Ophthalmol 2009;57(5):381-384 [FREE Full text] [doi: 10.4103/0301-4738.55078] [Medline: 19700877]

29. Manoharan G, Dharmarajan S, Ramalingam PK, Mathew S, Varghese JC. Mobile phone communication and health system strengthening: a pilot study of telephonic warmline consultation in HIV care and support in South India. J Int Assoc Physicians AIDS Care (Chic) 2012;11(3):184-187. [doi: 10.1177/1545109711428010] [Medline: 22357374]

30. Rodrigues R, Shet A, Antony J, Sidney K, Arumugam K, Krishnamurthy S, et al. Supporting adherence to antiretroviral therapy with mobile phone reminders: results from a cohort in South India. PLoS One 2012;7(8):e40723 [FREE Full text] [doi: 10.1371/journal.pone.0040723] [Medline: 22952574]

31. Sidney K, Antony J, Rodrigues R, Arumugam K, Krishnamurthy S, D'souza G, et al. Supporting patient adherence to antiretrovirals using mobile phone reminders: patient responses from South India. AIDS Care 2012;24(5):612-617. [doi: 10.1080/09540121.2011.630357] [Medline: 22150088]

32. Swendeman D, Jana S, Ray P, Mindry D, Das M, Bhakta B. Development and pilot testing of daily interactive voice response (IVR) calls to support antiretroviral adherence in India: a mixed-methods pilot study. AIDS Behav 2015 Jun;19 Suppl 2:142-155 [FREE Full text] [doi: 10.1007/s10461-014-0983-9] [Medline: 25638037]

33. Thakkar J, Karthikeyan G, Purohit G, Thakkar S, Sharma J, Verma S, et al. Development of macaronic Hindi-English 'Hinglish' text message content for a coronary heart disease secondary prevention programme. Heart Asia 2016;8(2):32-38 [FREE Full text] [doi: 10.1136/heartasia-2016-010789] [Medline: 27752288]

34. Kaliyadan F, Venkitakrishnan S. Teledermatology: clinical case profiles and practical issues. Indian J Dermatol Venereol Leprol 2009;75(1):32-35 [FREE Full text] [Medline: 19172028]

35. De Costa A, Shet A, Kumarasamy N, Ashorn P, Eriksson B, Bogg L, HIVIND study team. Design of a randomized trial to evaluate the influence of mobile phone reminders on adherence to first line antiretroviral treatment in South India--the HIVIND study protocol. BMC Med Res Methodol 2010 Mar 26;10:25 [FREE Full text] [doi: 10.1186/1471-2288-10-25] [Medline: 20346136]

36. Singh M, Das RR. Utility of telemedicine for children in India. Indian J Pediatr 2010 Jan;77(1):73-75. [doi: 10.1007/s12098-009-0292-x] [Medline: 20091379]

37. Singh M, Das RR. Four years of experience of telemedicine for paediatric care in three Punjab hospitals, North India: achievements and lessons. Postgrad Med J 2010 Dec;86(1022):688-691. [doi: 10.1136/pgmj.2009.082735] [Medline: 20870650]

38. Alexander G, Kanth C, Thomas R. A descriptive study on the users and utility of HIV/AIDS helpline in Karnataka, India. Indian J Community Med 2011 Jan;36(1):17-20 [FREE Full text] [doi: 10.4103/0970-0218.80787] [Medline: 21687375]

39. Agrawal D. Transforming trauma healthcare delivery in rural areas by use of an integrated call center. J Emerg Trauma Shock 2012 Jan;5(1):7-10 [FREE Full text] [doi: 10.4103/0974-2700.93099] [Medline: 22416147] 
40. Kesavadev J, Shankar A, Pillai PB, Krishnan G, Jothydev S. Cost-effective use of telemedicine and self-monitoring of blood glucose via Diabetes Tele Management System (DTMS) to achieve target glycosylated hemoglobin values without serious symptomatic hypoglycemia in 1,000 subjects with type 2 diabetes mellitus--a retrospective study. Diabetes Technol Ther 2012 Sep;14(9):772-776. [doi: 10.1089/dia.2012.0088] [Medline: 22734662]

41. Schneider JA, Kondareddy D, Gandham S, Dude AM. Using digital communication technology fails to improve longitudinal evaluation of an HIV prevention program aimed at Indian truck drivers and cleaners. AIDS Behav 2012 Jul;16(5):1359-1363 [FREE Full text] [doi: 10.1007/s10461-011-0060-6] [Medline: 21983800]

42. Praveen D, Patel A, McMahon S, Prabhakaran D, Clifford GD, Maulik PK, et al. A multifaceted strategy using mobile technology to assist rural primary healthcare doctors and frontline health workers in cardiovascular disease risk management: protocol for the SMARTHealth India cluster randomised controlled trial. Implement Sci 2013 Nov 25;8:137 [FREE Full text] [doi: 10.1186/1748-5908-8-137] [Medline: 24274431]

43. Rachapelle S, Legood R, Alavi Y, Lindfield R, Sharma T, Kuper H, et al. The cost-utility of telemedicine to screen for diabetic retinopathy in India. Ophthalmology 2013 Mar;120(3):566-573. [doi: 10.1016/j.ophtha.2012.09.002] [Medline: 23211635]

44. Agrawal A, Tiwari A. Tele-recruitment for donor retention. Indian J Hematol Blood Transfus 2014 Mar;30(1):22-25 [FREE Full text] [doi: 10.1007/s12288-012-0197-0] [Medline: 24554816]

45. Arora M, Harvey LA, Hayes AJ, Chhabra HS, Glinsky JV, Cameron ID, et al. Effectiveness and cost-effectiveness of telephone-based support versus usual care for treatment of pressure ulcers in people with spinal cord injury in low-income and middle-income countries: study protocol for a 12-week randomised controlled trial. Br Med J Open 2015 Jul 28;5(7):e008369 [FREE Full text] [doi: 10.1136/bmjopen-2015-008369] [Medline: 26220871]

46. Smith R, Menon J, Rajeev JG, Feinberg L, Kumar RK, Banerjee A. Potential for the use of mHealth in the management of cardiovascular disease in Kerala: a qualitative study. Br Med J Open 2015 Nov 17;5(11):e009367 [FREE Full text] [doi: 10.1136/bmjopen-2015-009367] [Medline: 26576813]

47. Sureshkumar K, Murthy GV, Kinra S, Goenka S, Kuper H. Development and evaluation of a smartphone-enabled, caregiver-supported educational intervention for management of physical disabilities following stroke in India: protocol for a formative research study. Br Med J Innov $2015 \mathrm{Jul}$;1(3):117-126 [FREE Full text] [doi: 10.1136/bmjinnov-2015-000042] [Medline: 26751379]

48. Thomas B, Closson EF, Biello K, Menon S, Navakodi P, Dhanalakshmi A, et al. Development and open pilot trial of an HIV-prevention intervention integrating mobile-phone technology for male sex workers in Chennai, India. Arch Sex Behav 2017 May;46(4):1035-1046 [FREE Full text] [doi: 10.1007/s10508-015-0665-3] [Medline: 26714684]

49. Balakrishnan R, Gopichandran V, Chaturvedi S, Chatterjee R, Mahapatra T, Chaudhuri I. Continuum of Care Services for maternal and child health using mobile technology - a health system strengthening strategy in low and middle income countries. BMC Med Inform Decis Mak 2016 Jul 7;16:84 [FREE Full text] [doi: 10.1186/s12911-016-0326-z] [Medline: 27387548]

50. Ganesan AN, Louise J, Horsfall M, Bilsborough SA, Hendriks J, McGavigan AD, et al. International mobile-health intervention on physical activity, sitting, and weight: the Stepathlon cardiovascular health study. J Am Coll Cardiol 2016 May 31;67(21):2453-2463 [FREE Full text] [doi: 10.1016/j.jacc.2016.03.472] [Medline: 27050185]

51. Gupta RS, Yewale K, Hegde AS, Mulik T, Bamrotiya M, Yadav S, et al. Use of technology in follow-up of HIV positive pregnant women and their babies till 18 months of age- an innovation by Maharashtra State AIDS Control Society (MSACS), India. Curr Opin HIV AIDS 2016 Mar;11 Suppl 1:S46-S51 [FREE Full text] [doi: 10.1097/COH.0000000000000265] [Medline: 26945142]

52. Jadhav HC, Dodamani AS, Karibasappa GN, Naik RG, Khairnar MR, Deshmukh MA, et al. Effect of reinforcement of oral health education message through short messaging service in mobile phones: a quasi-experimental trial. Int J Telemed Appl 2016;2016:7293516 [FREE Full text] [doi: 10.1155/2016/7293516] [Medline: 26941793]

53. Madan Kumar PD, Mohandoss AA, Walls T, Rooban T, Vernon LT. Using smartphone video "selfies" to monitor change in toothbrushing behavior after a brief intervention: a pilot study. Indian J Dent Res 2016;27(3):268-277 [FREE Full text] [doi: 10.4103/0970-9290.186241] [Medline: 27411655]

54. Pfammatter A, Spring B, Saligram N, Davé R, Gowda A, Blais L, et al. mHealth intervention to improve diabetes risk behaviors in India: a prospective, parallel group cohort study. J Med Internet Res 2016 Aug 5;18(8):e207 [FREE Full text] [doi: 10.2196/jmir.5712] [Medline: 27496271]

55. Prinja S, Nimesh R, Gupta A, Bahuguna P, Thakur JS, Gupta M, et al. Impact assessment and cost-effectiveness of m-health application used by community health workers for maternal, newborn and child health care services in rural Uttar Pradesh, India: a study protocol. Glob Health Action 2016;9:31473 [FREE Full text] [Medline: 27189200]

56. Reynolds NR, Satyanarayana V, Duggal M, Varghese M, Liberti L, Singh P, et al. MAHILA: a protocol for evaluating a nurse-delivered mHealth intervention for women with HIV and psychosocial risk factors in India. BMC Health Serv Res 2016 Dec 4;16(a):352 [FREE Full text] [doi: 10.1186/s12913-016-1605-1] [Medline: 27491288]

57. Robin M, Xavier T, Agrawal D. Use of nurses in tele-consultation for patients in remote areas. Stud Health Technol Inform 2016;225:113-117. [Medline: 27332173] 
58. Bali S, Singh AJ. Mobile phone consultation for community health care in rural north India. J Telemed Telecare 2007;13(8):421-424. [doi: 10.1258/135763307783064421] [Medline: 18078555]

59. Mishra A, Kapoor L, Mishra SK. Post-operative care through tele-follow up visits in patients undergoing thyroidectomy and parathyroidectomy in a resource-constrained environment. J Telemed Telecare 2009;15(2):73-76. [doi: 10.1258/jtt.2008.080808] [Medline: $\underline{19246606}$ ]

60. Mohan V, Deepa M, Pradeepa R, Prathiba V, Datta M, Sethuraman R, et al. Prevention of diabetes in rural India with a telemedicine intervention. J Diabetes Sci Technol 2012;6(6):1355-1364 [FREE Full text] [Medline: 23294780]

61. Elangovan R, Arulchelvan S. A study on the role of mobile phone communication in tuberculosis DOTS treatment. Indian J Community Med 2013 Oct;38(4):229-233. [doi: 10.4103/0970-0218.120158] [Medline: 24302824]

62. Ramkumar V, Hall JW, Nagarajan R, Shankarnarayan VC, Kumaravelu S. Tele-ABR using a satellite connection in a mobile van for newborn hearing testing. J Telemed Telecare 2013 Jul;19(5):233-237. [doi: 10.1177/1357633X13494691] [Medline: 24163231]

63. Balasinorwala VP, Shah NB, Chatterjee SD, Kale VP, Matcheswalla YA. Asynchronous telepsychiatry in maharashtra, India: study of feasibility and referral pattern. Indian J Psychol Med 2014 Jul;36(3):299-301 [FREE Full text] [doi: 10.4103/0253-7176.135384] [Medline: 25035555]

64. Chandra PS, Sowmya HR, Mehrotra S, Duggal M. 'SMS' for mental health-feasibility and acceptability of using text messages for mental health promotion among young women from urban low income settings in India. Asian J Psychiatr 2014 Oct;11:59-64. [doi: 10.1016/j.ajp.2014.06.008] [Medline: 25453699]

65. Datta SS, Ranganathan P, Sivakumar KS. A study to assess the feasibility of text messaging service in delivering maternal and child healthcare messages in a rural area of Tamil Nadu, India. Australas Med J 2014;7(4):175-180 [FREE Full text] [doi: 10.4066/AMJ.2014.1916] [Medline: 24817911]

66. DeSouza SI, Rashmi MR, Vasanthi AP, Joseph SM, Rodrigues R. Mobile phones: the next step towards healthcare delivery in rural India? PLoS One 2014;9(8):e104895 [FREE Full text] [doi: 10.1371/journal.pone.0104895] [Medline: 25133610]

67. Gupta S, Dewan S, Kaushal A, Seth A, Narula J, Varma A. eICU reduces mortality in STEMI patients in resource-limited areas. Glob Heart 2014 Dec;9(4):425-427. [doi: 10.1016/j.gheart.2014.07.006] [Medline: 25592796]

68. Agarwal A, Hamdallah M, Swain SN, Mukherjee S, Singh N, Mahapatra S, et al. Implementation of a confidential helpline for men having sex with men in India. JMIR Mhealth Uhealth 2015 Feb 11;3(1):e17 [FREE Full text] [doi: 10.2196/mhealth.3978] [Medline: 25673240]

69. Priscilla S, Nanditha A, Simon M, Satheesh K, Kumar S, Shetty AS, et al. A pragmatic and scalable strategy using mobile technology to promote sustained lifestyle changes to prevent type 2 diabetes in India-Outcome of screening. Diabetes Res Clin Pract 2015 Dec;110(3):335-340. [doi: 10.1016/j.diabres.2015.09.004] [Medline: 26547503]

70. Sureshkumar K, Murthy GV, Munuswamy S, Goenka S, Kuper H. 'Care for Stroke', a web-based, smartphone-enabled educational intervention for management of physical disabilities following stroke: feasibility in the Indian context. BMJ Innov 2015 Jul;1(3):127-136 [FREE Full text] [doi: 10.1136/bmjinnov-2015-000056] [Medline: 26246902]

71. Ajay VS, Jindal D, Roy A, Venugopal V, Sharma R, Pawar A, et al. Development of a smartphone-enabled hypertension and diabetes mellitus management package to facilitate evidence-based care delivery in primary healthcare facilities in India: the mPower heart project. J Am Heart Assoc 2016 Dec 21;5(12) [FREE Full text] [doi: 10.1161/JAHA.116.004343] [Medline: 28003248]

72. Sureshkumar K, Murthy G, Natarajan S, Naveen C, Goenka S, Kuper H. Evaluation of the feasibility and acceptability of the 'Care for Stroke' intervention in India, a smartphone-enabled, carer-supported, educational intervention for management of disability following stroke. Br Med J Open 2016 Feb 2;6(2):e009243 [FREE Full text] [doi: 10.1136/bmjopen-2015-009243] [Medline: 26839011]

73. Monica SD, Ramkumar V, Krumm M, Raman N, Nagarajan R, Venkatesh L. School entry level tele-hearing screening in a town in South India - lessons learnt. Int J Pediatr Otorhinolaryngol 2017 Jan;92:130-135. [doi: 10.1016/j.ijporl.2016.11.021] [Medline: 28012514]

74. Morjaria P, Bastawrous A, Murthy GV, Evans J, Gilbert C. Effectiveness of a novel mobile health education intervention (Peek) on spectacle wear among children in India: study protocol for a randomized controlled trial. Trials 2017 Dec 8;18(1):168 [FREE Full text] [doi: 10.1186/s13063-017-1888-5] [Medline: 28388923]

75. Meher SK, Tyagi RS, Chaudhry T. Awareness and attitudes to telemedicine among doctors and patients in India. J Telemed Telecare 2009;15(3):139-141. [doi: 10.1258/jtt.2009.003011] [Medline: 19364898]

76. Shet A, Arumugam K, Rodrigues R, Rajagopalan N, Shubha K, Raj T, et al. Designing a mobile phone-based intervention to promote adherence to antiretroviral therapy in South India. AIDS Behav 2010 Jun;14(3):716-720. [doi: 10.1007/s10461-009-9658-3] [Medline: 20054634]

77. Laxmi V, Sharma S, Singh AK, Amadi C, Mohan K, Joshi A. Perceptions of online lifestyle counseling among individuals living in rural India. Technol Health Care 2014;22(4):597-606. [doi: 10.3233/THC-140837] [Medline: 24990171]

78. Priyaa S, Murthy S, Sharan S, Mohan K, Joshi A. A pilot study to assess perceptions of using SMS as a medium for health information in a rural setting. Technol Health Care 2014;22(1):1-11. [doi: 10.3233/THC-130766] [Medline: 24284551] 
79. Jain N, Singh H, Koolwal GD, Kumar S, Gupta A. Opportunities and barriers in service delivery through mobile phones (mHealth) for severe mental illnesses in Rajasthan, India: a multi-site study. Asian J Psychiatr 2015 Apr;14:31-35. [doi: 10.1016/j.ajp.2015.01.008] [Medline: 25701069]

80. Ramachandran N, Srinivasan M, Thekkur P, Johnson P, Chinnakali P, Naik BN. Mobile phone usage and willingness to receive health-related information among patients attending a chronic disease clinic in rural Puducherry, India. J Diabetes Sci Technol 2015 Aug 6;9(6):1350-1351 [FREE Full text] [doi: 10.1177/1932296815599005] [Medline: 26251372]

81. Rodrigues R, Poongulali S, Balaji K, Atkins S, Ashorn P, De Costa A. 'The phone reminder is important, but will others get to know about my illness?' Patient perceptions of an mHealth antiretroviral treatment support intervention in the HIVIND trial in South India. Br Med J Open 2015 Nov 2;5(11):e007574 [FREE Full text] [doi: 10.1136/bmjopen-2015-007574] [Medline: 26525717]

82. Acharya RV, Rai JJ. Evaluation of patient and doctor perception toward the use of telemedicine in Apollo Tele Health Services, India. J Family Med Prim Care 2016;5(4):798-803 [FREE Full text] [doi: 10.4103/2249-4863.201174] [Medline: 28348994]

83. Mudgapalli V, Sharan S, Amadi C, Joshi A. Perception of receiving SMS based health messages among hypertensive individuals in urban slums. Technol Health Care 2016;24(1):57-65. [doi: 10.3233/THC-151097] [Medline: 26484882]

84. Parthaje PM, Unnikrishnan B, Thapar R, Kumar N, Panikulam EJ, Geroge E, et al. Perceptions and knowledge toward mobile-health among the college going students in Coastal South India. J Nat Sci Biol Med 2016;7(1):75-79 [FREE Full text] [doi: 10.4103/0976-9668.175078] [Medline: 27003975]

85. Ramkumar V, Selvakumar K, Vanaja CS, Hall JW, Nagarajan R, Neethi J. Parents' perceptions of tele-audiological testing in a rural hearing screening program in South India. Int J Pediatr Otorhinolaryngol 2016 Oct;89:60-66. [doi: 10.1016/j.ijporl.2016.07.028] [Medline: 27619030]

86. Kumari Rani P, Raman R, Manikandan M, Mahajan S, Paul PG, Sharma T. Patient satisfaction with tele-ophthalmology versus ophthalmologist-based screening in diabetic retinopathy. J Telemed Telecare 2006;12(3):159-160. [doi: 10.1258/135763306776738639] [Medline: 16638238]

87. Paul PG, Raman R, Rani PK, Deshmukh H, Sharma T. Patient satisfaction levels during teleophthalmology consultation in rural South India. Telemed J E Health 2006 Oct;12(5):571-578. [doi: 10.1089/tmj.2006.12.571] [Medline: 17042711]

88. Martínez Álvarez M, Chanda R, Smith RD. How is Telemedicine perceived? A qualitative study of perspectives from the UK and India. Global Health 2011 May 20;7:17 [FREE Full text] [doi: 10.1186/1744-8603-7-17] [Medline: 21599962]

89. Nahar P, Kannuri NK, Mikkilineni S, Murthy GV, Phillimore P. mHealth and the management of chronic conditions in rural areas: a note of caution from southern India. Anthropol Med 2017 Apr;24(1):1-16 [FREE Full text] [doi: 10.1080/13648470.2016.1263824] [Medline: 28292206]

90. Deodhar J. Telemedicine by email--experience in neonatal care at a primary care facility in rural India. J Telemed Telecare 2002;8 Suppl 2:20-21. [doi: $10.1177 / 1357633$ X020080S209] [Medline: $\underline{12217120}$ ]

91. Jialdasani R, Desai S, Gupta M, Kothari A, Deshpande R, Shet T, et al. An analysis of 46 static telecytology cases over a period of two years. J Telemed Telecare 2006;12(6):311-314. [doi: 10.1258/135763306778558132] [Medline: 17022840]

92. Keeppanasserril A, Matthew A, Muddappa S. Effectiveness of tele-guided interceptive prosthodontic treatment in rural India: a comparative pilot study. Online J Public Health Inform 2011;3(2) [FREE Full text] [doi: 10.5210/ojphi.v3i2.3800] [Medline: 23569611]

93. Mahadevan S, Muralidhar K, Shetty D. Tele-education service using telemedicine network in healthcare industry. Telemed J E Health 2012 Nov;18(9):699-702. [doi: 10.1089/tmj.2011.0278] [Medline: 23046243]

94. Agrawal R, Mishra SK, Mishra A, Chand G, Agarwal G, Agarwal A, et al. Role of telemedicine technology in endocrine surgery knowledge sharing. Telemed J E Health 2014 Sep;20(9):868-874. [doi: 10.1089/tmj.2013.0164] [Medline: 25078673]

95. Thukral A, Joshi M, Joshi P, Prakash V, Adkoli BV, Deorari AK. Apps for management of sick newborn: evaluation of impact on health care professionals. J Trop Pediatr 2014 Oct;60(5):370-376. [doi: 10.1093/tropej/fmu032] [Medline: $\underline{24924579]}$

96. Khanna V, Sambandam SN, Gul A, Mounasamy V. "WhatsApp"ening in orthopedic care: a concise report from a 300-bedded tertiary care teaching center. Eur J Orthop Surg Traumatol 2015 Jul;25(5):821-826. [doi: 10.1007/s00590-015-1600-y] [Medline: 25633127]

97. Raghu A, Praveen D, Peiris D, Tarassenko L, Clifford G. Engineering a mobile health tool for resource-poor settings to assess and manage cardiovascular disease risk: SMARThealth study. BMC Med Inform Decis Mak 2015 Apr 29;15:36 [FREE Full text] [doi: 10.1186/s12911-015-0148-4] [Medline: 25924825]

98. Chanani S, Wacksman J, Deshmukh D, Pantvaidya S, Fernandez A, Jayaraman A. M-Health for improving screening accuracy of acute malnutrition in a community-based management of acute malnutrition program in mumbai informal settlements. Food Nutr Bull 2016 Dec;37(4):504-516. [doi: 10.1177/0379572116657241] [Medline: 27370976]

99. Dorwal P, Sachdev R, Gautam D, Jain D, Sharma P, Tiwari AK, et al. Role of WhatsApp messenger in the laboratory management system: a boon to communication. J Med Syst 2016 Jan;40(1):14. [doi: 10.1007/s10916-015-0384-2] [Medline: 26573651] 
100. Kaliyadan F, Ashique KT, Jagadeesan S, Krishna B. What's up dermatology? A pilot survey of the use of WhatsApp in dermatology practice and case discussion among members of WhatsApp dermatology groups. Indian J Dermatol Venereol Leprol 2016;82(1):67-69 [FREE Full text] [doi: 10.4103/0378-6323.171638] [Medline: 26728815]

101. George JT, Rozario KS, Abraham A. A survey in India of doctors' knowledge, attitudes and practice regarding telemedicine and e-health. J Telemed Telecare 2007;13(6):322. [doi: 10.1258/135763307781644924] [Medline: 17785030]

102. Agarwal S, Lau CT. Remote health monitoring using mobile phones and Web services. Telemed J E Health 2010 Jun;16(5):603-607. [doi: 10.1089/tmj.2009.0165] [Medline: 20575728]

103. Chattopadhyay S. A framework for studying perceptions of rural healthcare staff and basic ICT support for e-health use: an Indian experience. Telemed J E Health 2010;16(1):80-88. [doi: 10.1089/tmj.2009.0081] [Medline: 20070160]

104. Gour N, Srivastava D. Knowledge of computer among healthcare professionals of India: a key toward e-health. Telemed J E Health 2010 Nov;16(9):957-962. [doi: 10.1089/tmj.2010.0049] [Medline: 21091287]

105. Boringi M, Waghray S, Lavanya R, Babu DB, Badam RK, Harsha N, et al. Knowledge and awareness of teledentistry among dental professionals - a cross sectional study. J Clin Diagn Res 2015 Aug;9(8):ZC41-ZC44 [FREE Full text] [doi: 10.7860/JCDR/2015/13303.6320] [Medline: 26436045]

106. Ganapathy K, Kanwar V, Bhatnagar T, Uthayakumaran N. m-Health: a critical analysis of awareness, perception, and attitude of healthcare among providers in Himachal Pradesh, North India. Telemed J E Health 2016 Dec;22(8):675-688. [doi: 10.1089/tmj.2015.0198] [Medline: 26859179]

107. Patil RN, Almale BD, Patil M, Gujrathi A, Dhakne-Palwe S, Patil AR, et al. Attitudes and perceptions of medical undergraduates towards mobile learning (M-learning). J Clin Diagn Res 2016 Oct;10(10):JC06-JC10 [FREE Full text] [doi: 10.7860/JCDR/2016/20214.8682] [Medline: 27891356]

108. Vivek C, Vikrant K. Tele-ECG and 24-hour physician support over telephone for rural doctors can help early treatment of acute myocardial infarction in rural areas. J Telemed Telecare 2016 Apr;22(3):203-206. [doi: 10.1177/1357633X15592734] [Medline: 26187625]

109. Praveen D, Patel A, Raghu A, Clifford GD, Maulik PK, Mohammad AA, et al. SMARTHealth India: development and field evaluation of a mobile clinical decision support system for cardiovascular diseases in rural India. JMIR Mhealth Uhealth 2014 Dec 8;2(4):e54 [FREE Full text] [doi: 10.2196/mhealth.3568] [Medline: 25487047]

110. Kaphle S, Chaturvedi S, Chaudhuri I, Krishnan R, Lesh N. Adoption and usage of mHealth technology on quality and experience of care provided by frontline workers: observations from rural India. JMIR Mhealth Uhealth 2015 May 28;3(2):e61 [FREE Full text] [doi: 10.2196/mhealth.4047] [Medline: 26023001]

111. Modi D, Gopalan R, Shah S, Venkatraman S, Desai G, Desai S, et al. Development and formative evaluation of an innovative mHealth intervention for improving coverage of community-based maternal, newborn and child health services in rural areas of India. Glob Health Action 2015;8:26769 [FREE Full text] [Medline: 25697233]

112. Maulik PK, Tewari A, Devarapalli S, Kallakuri S, Patel A. The systematic medical appraisal, referral and treatment (smart) mental health project: development and testing of electronic decision support system and formative research to understand perceptions about mental health in rural India. PLoS One 2016;11(10):e0164404 [FREE Full text] [doi: 10.1371/journal.pone.0164404] [Medline: 27732652]

113. Maulik PK, Kallakuri S, Devarapalli S, Vadlamani VK, Jha V, Patel A. Increasing use of mental health services in remote areas using mobile technology: a pre-post evaluation of the SMART Mental Health project in rural India. J Glob Health 2017 Jun;7(1):010408 [FREE Full text] [doi: 10.7189/jogh.07.010408] [Medline: 28400954]

114. Perumalsamy N, Prasad NM, Sathya S, Ramasamy K. Software for reading and grading diabetic retinopathy: Aravind Diabetic Retinopathy Screening 3.0. Diabetes Care 2007 Sep;30(9):2302-2306. [doi: 10.2337/dc07-0225] [Medline: 17507695]

115. Srinivasan K, Ramesh SV, Babu N, Sanker N, Ray A, Karuna SM. Efficacy of a remote based computerised visual acuity measurement. Br J Ophthalmol 2012 Jul;96(7):987-990. [doi: 10.1136/bjophthalmol-2012-301751] [Medline: 22539747]

116. Gupta SC, Sinha SK, Dagar AB. Evaluation of the effectiveness of diagnostic \& management decision by teleophthalmology using indigenous equipment in comparison with in-clinic assessment of patients. Indian J Med Res 2013 Oct;138(4):531-535 [FREE Full text] [Medline: 24434260]

117. Raman R, Bhojwani DN, Sharma T. How accurate is the diagnosis of diabetic retinopathy on telescreening? The Indian scenario. Rural Remote Health 2014;14(4):2809 [FREE Full text] [Medline: 25349110]

118. Sreelatha OK, Ramesh SV, Jose J, Devassy M, Srinivasan K. Virtually controlled computerised visual acuity screening in a multilingual Indian population. Rural Remote Health 2014;14(3):2908 [FREE Full text] [Medline: 25190644]

119. Rajalakshmi R, Arulmalar S, Usha M, Prathiba V, Kareemuddin KS, Anjana RM, et al. Validation of smartphone based retinal photography for diabetic retinopathy screening. PLoS One 2015;10(9):e0138285 [FREE Full text] [doi: 10.1371/journal.pone.0138285] [Medline: 26401839]

120. Ryan ME, Rajalakshmi R, Prathiba V, Anjana RM, Ranjani H, Narayan KM, et al. Comparison among methods of retinopathy assessment (CAMRA) study: smartphone, nonmydriatic, and mydriatic photography. Ophthalmology 2015 Oct;122(10):2038-2043 [FREE Full text] [doi: 10.1016/j.ophtha.2015.06.011] [Medline: 26189190] 
121. Imtiaz SA, Krishnaiah S, Yadav SK, Bharath B, Ramani RV. Benefits of an Android based tablet application in primary screening for eye diseases in a rural population, India. J Med Syst 2017 Apr;41(4):49. [doi: 10.1007/s10916-017-0695-6] [Medline: 28210832]

122. Bedekar N, Suryawanshi M, Rairikar S, Sancheti P, Shyam A. Inter and intra-rater reliability of mobile device goniometer in measuring lumbar flexion range of motion. J Back Musculoskelet Rehabil 2014;27(2):161-166. [doi: 10.3233/BMR-130431] [Medline: 24029833]

123. Malhotra S, Chakrabarti S, Shah R, Gupta A, Mehta A, Nithya B, et al. Development of a novel diagnostic system for a telepsychiatric application: a pilot validation study. BMC Res Notes 2014 Aug 9;7:508 [FREE Full text] [doi: 10.1186/1756-0500-7-508] [Medline: 25106438]

124. Singh M, Agarwal A, Sinha V, Manoj Kumar R, Jaiswal N, Jindal I, et al. Application of handheld tele-ECG for health care delivery in rural India. Int J Telemed Appl 2014;2014:981806 [FREE Full text] [doi: 10.1155/2014/981806] [Medline: 25368654]

125. Patterson V, Singh M, Rajbhandari H, Vishnubhatla S. Validation of a phone app for epilepsy diagnosis in India and Nepal. Seizure 2015 Aug;30:46-49 [FREE Full text] [doi: 10.1016/j.seizure.2015.05.011] [Medline: 26216684]

126. Shrivastav M, Padte S, Sinha N. Patient experience with a novel patch-like external loop recorder for cardiac arrhythmia detection in India. Expert Rev Med Devices 2014 May;11(3):259-264. [doi: 10.1586/17434440.2014.894457] [Medline: 24678585]

127. Negandhi P, Chauhan M, Das AM, Neogi SB, Sharma J, Sethy G. Mobile-based effective vaccine management tool: An m-health initiative implemented by UNICEF in Bihar. Indian J Public Health 2016;60(4):334-335 [FREE Full text] [doi: 10.4103/0019-557X.195869] [Medline: 27976659]

128. Krishnan A, Nongkynrih B, Yadav K, Singh S, Gupta V. Evaluation of computerized health management information system for primary health care in rural India. BMC Health Serv Res 2010 Nov 16;10:310 [FREE Full text] [doi: 10.1186/1472-6963-10-310] [Medline: 21078203]

129. Giduthuri JG, Maire N, Joseph S, Kudale A, Schaetti C, Sundaram N, et al. Developing and validating a tablet version of an illness explanatory model interview for a public health survey in Pune, India. PLoS One 2014;9(9):e107374 [FREE Full text] [doi: 10.1371/journal.pone.0107374] [Medline: 25233212]

130. Radhakrishna K, Goud BR, Kasthuri A, Waghmare A, Raj T. Electronic health records and information portability: a pilot study in a rural primary healthcare center in India. Perspect Health Inf Manag 2014;11:1b [FREE Full text] [Medline: 25214819]

131. Diwan V, Agnihotri D, Hulth A. Collecting syndromic surveillance data by mobile phone in rural India: implementation and feasibility. Glob Health Action 2015;8:26608 [FREE Full text] [Medline: 25843499]

132. Pathak A, Sharma S, Sharma M, Mahadik VK, Lundborg CS. Feasibility of a mobile phone-based surveillance for surgical site infections in rural India. Telemed J E Health 2015 Nov;21(11):946-949 [FREE Full text] [doi: 10.1089/tmj.2014.0199] [Medline: 25748641]

133. Velayutham B, Thomas B, Nair D, Thiruvengadam K, Prashant S, Kittusami S, et al. The usefulness and feasibility of mobile interface in tuberculosis notification (MITUN) voice based system for notification of tuberculosis by private medical practitioners--a pilot project. PLoS One 2015;10(9):e0138274 [FREE Full text] [doi: 10.1371/journal.pone.0138274] [Medline: 26376197]

134. Kazi DS, Greenough PG, Madhok R, Heerboth A, Shaikh A, Leaning J, et al. Using mobile technology to optimize disease surveillance and healthcare delivery at mass gatherings: a case study from India's Kumbh Mela. J Public Health (Oxf) 2017 Sep 1;39(3):616-624 [FREE Full text] [doi: 10.1093/pubmed/fdw091] [Medline: 27694349]

135. Modi D, Patel J, Desai S, Shah P. Accessing completeness of pregnancy, delivery, and death registration by Accredited Social Health Activists [ASHA] in an innovative mHealth project in the tribal areas of Gujarat: a cross-sectional study. $\mathbf{J}$ Postgrad Med 2016;62(3):170-172 [FREE Full text] [doi: 10.4103/0022-3859.183168] [Medline: 27241808]

136. Negandhi P, Chauhan M, Das AM, Sharma J, Neogi S, Sethy G. Computer tablet-based health technology for strengthening maternal and child tracking in Bihar. Indian J Public Health 2016;60(4):329-333 [FREE Full text] [doi: 10.4103/0019-557X.195868] [Medline: 27976658]

137. Gupta NJ, Kumar V, Panda S. A camera-phone based study reveals erratic eating pattern and disrupted daily eating-fasting cycle among adults in India. PLoS One 2017;12(3):e0172852 [FREE Full text] [doi: 10.1371/journal.pone.0172852] [Medline: 28264001]

138. Bradley J, Ramesh BM, Rajaram S, Lobo A, Gurav K, Isac S, et al. The feasibility of using mobile phone technology for sexual behaviour research in a population vulnerable to HIV: a prospective survey with female sex workers in South India. AIDS Care 2012;24(6):695-703. [doi: 10.1080/09540121.2011.630371] [Medline: 22292915]

139. Taneja U, Sushil. e-Healthcare in India: critical success factors for sustainable health systems. Stud Health Technol Inform 2007;129(Pt 1):257-261. [Medline: 17911718]

140. Meher SK, Biswas A, Ratha BK. Legal issues among doctors in the implementation of teleconsultation: a study at AIIMS, New Delhi, India. Stud Health Technol Inform 2013;192:1107. [Medline: 23920881]

141. Jarosławski S, Saberwal G. In eHealth in India today, the nature of work, the challenges and the finances: an interview-based study. BMC Med Inform Decis Mak 2014 Jan 6;14:1 [FREE Full text] [doi: 10.1186/1472-6947-14-1] [Medline: 24387627] 
142. Tian M, Zhang J, Luo R, Chen S, Petrovic D, Redfern J, et al. mHealth interventions for health system strengthening in China: a systematic review. JMIR Mhealth Uhealth 2017 Mar 16;5(3):e32 [FREE Full text] [doi: 10.2196/mhealth.6889] [Medline: 28302597]

143. Indian Council of Medical Research PHFI and IHME. Healthdata. 2017. India: Health of the Nation's States - The State-level Disease Burden URL: http://www.healthdata.org/sites/default/files/files/policy report/2017/

India Health of the Nation\%27s States Report 2017.pdf; [WebCite Cache ID 70WqJdsPK]

144. Shuchman M. The promise and pitfalls of global mHealth. Can Med Assoc J 2014 Oct 21;186(15):1134-1135 [FREE Full text] [doi: 10.1503/cmaj.109-4861] [Medline: 25183722]

\section{Abbreviations \\ IT: information technology \\ mHealth: mobile health \\ NCD: noncommunicable disease \\ RCT: randomized controlled trial \\ WHO: World Health Organization}

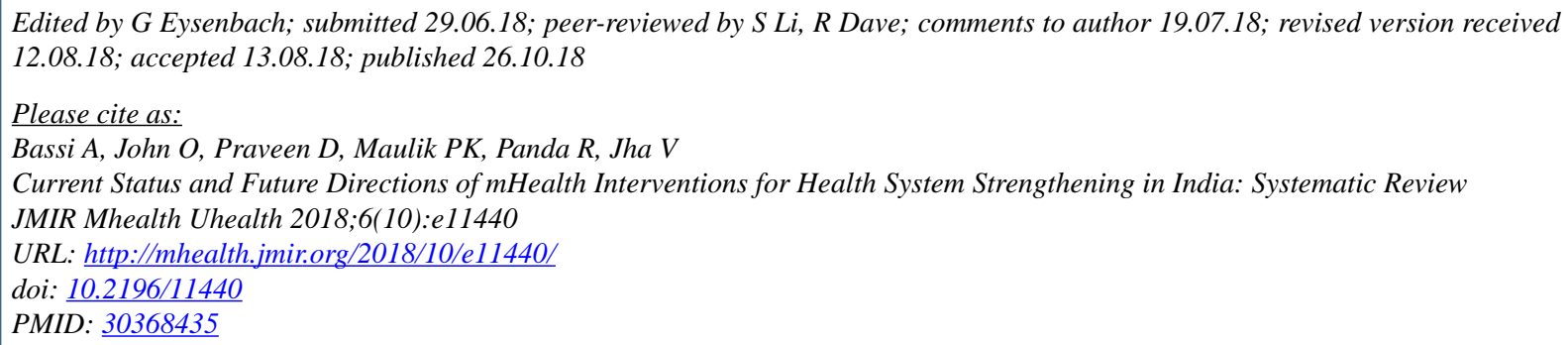

(C)Abhinav Bassi, Oommen John, Devarsetty Praveen, Pallab K Maulik, Rajmohan Panda, Vivekanand Jha. Originally published in JMIR Mhealth and Uhealth (http://mhealth.jmir.org), 26.10.2018. This is an open-access article distributed under the terms of the Creative Commons Attribution License (https://creativecommons.org/licenses/by/4.0/), which permits unrestricted use, distribution, and reproduction in any medium, provided the original work, first published in JMIR mhealth and uhealth, is properly cited. The complete bibliographic information, a link to the original publication on http://mhealth.jmir.org/, as well as this copyright and license information must be included. 